\title{
Effect of Black Carbon Composition on Hardness, Strength, Wear Resistance and Grip Coefficient of Tire Compound
}

\author{
Pramukollmu Purboputro ${ }^{1 *}$, , AgungSetyo Darmawan ${ }^{1}$, BambangWaluyo Febriantoko $^{1}$ \\ ${ }^{1}$ Department of Mechanical Engineering, Faculty of Engineering, \\ UniversitasMuhammadiyah Surakarta, Pabelan, Surakarta 57162, Indonesia
}

\section{ABSTRACT}

The purpose of this work was to investigate the effect of arrow pattern tire compound on hardness, wear resistance and grip coefficient in dry and wet operation conditions. The mixing compound would be consist of Rubber Smoked Sheet (RSS), Styrene Butadiene Rubber (SBR), Black Carbon, Paraffin oil, ZnO, Stearic Acid, Paraffin wax, Epoxy and Sulphur. The compound is mixed and heated to $100{ }^{\circ} \mathrm{C}$. After being cooled it is then conducted hardness test, performed wear test and tested for friction. The hardness and the tensile strength of the tire compound increase with increasing black carbon composition. While the wear of the tire compound decrease with increasing black carbon composition. There were no significant differences of grip coefficient when black carbon increased. However, grip coefficient will decrease by $12 \%$ when operating conditions change from dry asphalt track to wet asphalt track. The life of tire compound usage is increased by the addition of black carbon particles.

Key words: rubber tire compound, shore A hardness, wear , grip coefficient

\section{INTRODUCTION}

Vehicles roll on rubber tires that transfer friction force and wear out over the vehicle's lifetime. Vehicle tires are made of natural rubber because it excellent properties such as flexible and elastic[1]. In addition, the rubber material does not quickly absorb heat. Tires are made of vulcanized rubber and various reinforcing materials. The most commonly used rubber matrix is the co-polymer styrene-butadiene (SBR) or a blend of natural rubber and SBR[2]. In addition to the rubber compound, tires contain carbon black which is used to strengthen the rubber and improve abrasion resistance. Sulphur is also added in order to vulcanize the rubber compounds, transforming them into highly elastic material. Textile or steel fibers, usually in the form of a cord, used to provide the reinforcing strength or tensile component in tires[3-6].

Tires carry all types of loads or forces on the vehicle such as longitudinal and vertical braking, driving, cornering, and camber thrust to the road. This force is needed to control the direction of the vehicle. Traction tires are the result of friction generated in a variety of driving conditions such as cornering, braking and acceleration. That is a concept that illustrates the grip between the tire and the road [7-9].

Most of the grip is obtained if the tire comes in contact with the road surface at temperatures, optimal road conditions. In other to the four tires have maximum performance, they should be at the same temperature level. The coefficient of grip is also affected by the type of tire compound material and the tread surface of the tire. However the effects of tread wear and tyre age on the stiffness and friction coefficient of a tyre are not well understood[10-11].

Grip coefficient is very determining on a vehicle, because it will determine the driving force of a vehicle. Grip coefficient is strongly influenced by: the composition of the tire material, the type of road, road conditions, road temperature, and the tire load[12-13]. Indonesia is the second country in natural rubber production. Tire material research is dominated by Japan, France. Research has been done on a large scale, research on a small scale and portable has not been developed. For this reason, we want to develop this research on a portable scale, which can be generalized to its conditions.

The composition by adding sulphur is called a vulcanization reaction. The vulcanization reaction aims to increase the hardness of the tire material. Also in this case the carbon element is usually added. Sulphur element functions to break the double chain into a single chain, while the carbon element functions to add a new hydro carbon chain.

Sulphur is the main component of tire rubber compound that amount of 30- $50 \mathrm{phr}$ will increase tensile strength and hardness of tire rubber compound. Composition sulphur of $30-50 \mathrm{phr}$ and riclym of $20-40$ promote its good strain properly [14-15].

Carbon black has been widely used in automotive related rubber product applications[16]. The main function of carbon black in rubber is to increase the modulus [17]. Despite its particle size, Black Carbon is the most efficient filler, surface conditions and other properties can be combined widely. The property of the elastomer also determines the performance of the filler. A good material to improve the properties of certain rubbers, not certainly work equally well for other types of rubbers. Increasing the amount of filler causes an increase in the vulcanization 
properties. Black carbon is the only inexpensive material that can improve the three important properties of vulcanization, namely tensile strength, wear resistance and abrasion resistance[18].

Tire compounds release particulate wear products through mechanical abrasion. The wear of the tire compound contributes significantly to micro plastic pollution to the environment. Pollution caused by tire compounds is much higher than other sources of micro plastic pollution, eg.airplane tires, brake wear and synthetic grass [19]. Environmental pollution with plastic is recognized as a serious global threat because it can have a negative impact on the economy and human health[20].

In this work, the coefficient of grip research will be developed on a small scale, with parameters that will be developed and observed proportionally, so that the results can be considered close to the actual conditions. Research on the grip coefficient is still rarely done, because it requires quite large and expensive hardware. Micro-scale modeling of research allows results that are close to, at relatively little cost. An increase in grip coefficient will be carried out by mixing rubber compound from material: RSS (Sulphurized Smoked Rubber), SBR (Styrene Butadiene Rubber), Black Carbon, ZnO, SA (Stereic Acid) and Sulphur. RSS rubber and SBR rubber are rubber that functions as a tire material matrix. The purpose of the work is to investigate the effect of black carbon composition on hardness, wear resistance and grip coefficient of tire compound [21-22].

\section{MATERIALS AND METHODS}

The material for the tire compound used in this work is shown in Table 1. In the initial stages of compounding, the first thing to do is to weigh the ingredients according to the formulation of each compound. Then the ingredients are mixed one by one using a roll mixing machine. After mixing was completed, the results are called compounds (Figure 1). The vulcanization process was carried out at a temperature of $150{ }^{\circ} \mathrm{C}$.

\begin{tabular}{lcccc}
\multicolumn{5}{c}{ Table 1. Composition of tire compound composite } \\
\hline No & Materials & $\begin{array}{c}\text { Comp- } \\
\text { ound 1 } \\
\text { (phr) }\end{array}$ & $\begin{array}{c}\text { Comp- } \\
\text { ound 2 } \\
\text { (phr) }\end{array}$ & $\begin{array}{c}\text { Comp- } \\
\text { ound 3 } \\
\text { (phr) }\end{array}$ \\
\hline 1 & RSS & 70 & 70 & 70 \\
2 & SBR & 30 & 30 & 30 \\
3 & Black & 50 & 55 & 60 \\
4 & Carbon & 6 & 6 & 6 \\
5 & Parafin & 4 & 4 & 4 \\
6 & Oil & 2 & 2 & 2 \\
7 & ZnO & 0.5 & 0.5 & 0.5 \\
8 & Stearic & 1 & 1 & 1 \\
9 & Acid & 2 & 2 & 2 \\
10 & Parafin & 3.5 & 3.5 & 3.5 \\
& Wax & & & \\
& MBTS & & & \\
& Epoxy & & & \\
& Sulfur & & &
\end{tabular}

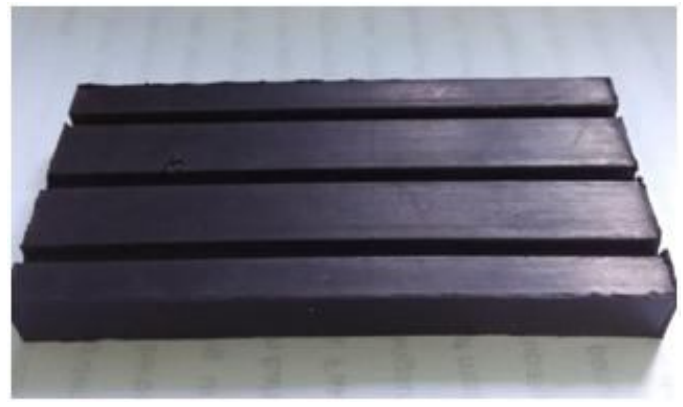

Figure 1: Compound product of vulcanization process.

After the vulcanization process was completed. There were three tests conducted, the first was hardness test with durometershore A type of hardness test. Then the second tensile test and the third friction test (grip coefficient test). However, the friction media which were originally in the form of disc disks are replaced with disks whose paths were already in the form of asphalt. The analysis was carried out to get the strongest friction of several specimens tested later. The conclusions contain the final test results of the test specimens.

\section{RESULTS AND DISCUSSIONS}

The results of hardness testing using the Durometer Shore A Hardness Tester can be seen in Figure 2. Compounds with black carbon contents of $50 \mathrm{phr}, 55 \mathrm{phr}$ and $60 \mathrm{phr}$ hadhardnesses of $63.7 \mathrm{HA}, 64.87 \mathrm{HA}$ and $71.17 \mathrm{HA}$, respectively. While the hardness of commercially tire compound was 53.37 HA. This shows that an increase in black carbon content from $50 \mathrm{phr}$ to $60 \mathrm{phr}$ increases the hardness of the tire compound by $12 \%$. Compounds with a black carbon content of $60 \mathrm{phr}$ had an increase in hardness of $33 \%$ compared to the hardness of a commercially tire compound. Figure 2 also shows that the tire compounds which were produced in this research from all black carbon variations were higher than the commercially tire compound hardness. The increase in hardness in the tire compound is caused by an increase in cross links due to carbon atoms.

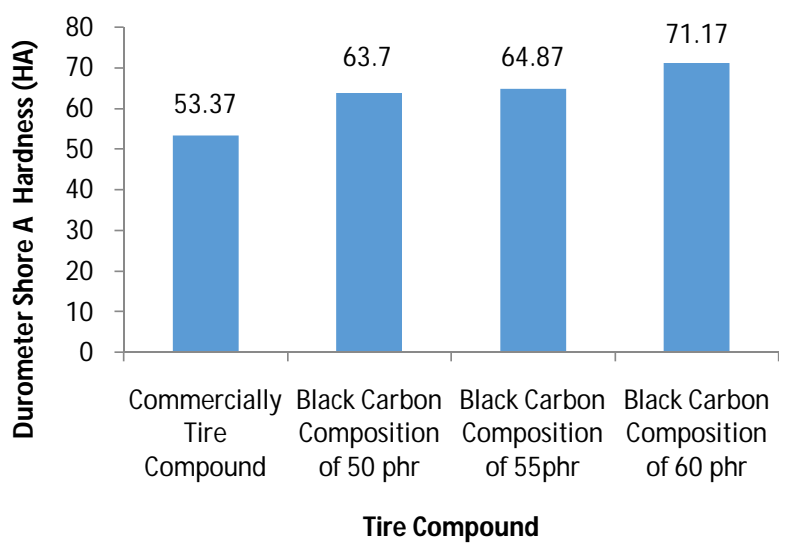

Figure 2: Effect of black carbon content on hardness and its comparison to commercially tire compound.

Tensile test results show the same tendency as hardness test results. This shows the existence of a linear relationship 
PramukoIlmu Purboputro et al., International Journal of Emerging Trends in Engineering Research, 8(9), September 2020, 5419 - 5423

between strength and hardness. Figure 3 shows the compounds with black carbon contents of $50 \mathrm{phr}, 55 \mathrm{phr}$ and $60 \mathrm{phr}$ had tensile strengths of $159.47 \mathrm{kgf} / \mathrm{mm}^{2}, 178.84$ $\mathrm{kgf} / \mathrm{mm}^{2}$ and $253.72 \mathrm{kgf} / \mathrm{mm}^{2}$, respectively. All compounds produced in this work had higher tensile strength than the tensile strength of commercially tire compounds. The highest increase in tensile strength in the carbon content range from $50 \mathrm{phr}$ to $60 \mathrm{phr}$ reaches $94 \%$.

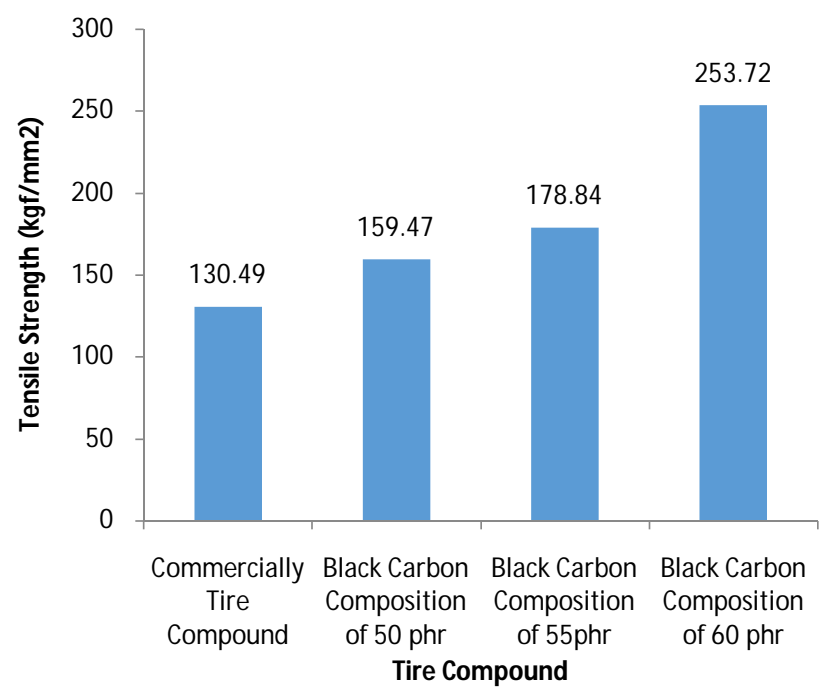

Figure 3: Effect of black carbon content on tensile strength and its comparison to commercially tire compound.

Tensile test results show the same tendency as hardness test results. This shows the existence of a linear relationship between strength and hardness. Figure 3 shows the compounds with black carbon contents of $50 \mathrm{phr}, 55 \mathrm{phr}$ and $60 \mathrm{phr}$ had tensile strengths of $159.47 \mathrm{kgf} / \mathrm{mm}^{2}, 178.84$ $\mathrm{kgf} / \mathrm{mm}^{2}$ and $253.72 \mathrm{kgf} / \mathrm{mm}^{2}$, respectively. All compounds produced in this work had higher tensile strength than the tensile strength of commercially tire compounds. The highest increase in tensile strength in the carbon content range from $50 \mathrm{phr}$ to $60 \mathrm{phr}$ reaches $94 \%$.

Wear test results can be seen in Figure 4. Wear is calculated from the difference in volume before and after the friction test divided by time. Wear on tire compound with operating conditions on dry asphalt track has decreased from black carbon composition of $50 \mathrm{phr}$ to $60 \mathrm{phr}$. Black carbon composition of $50 \mathrm{phr}$ produces a wear of $14 \mathrm{~m}^{3} / \mathrm{s}$. Black carbon composition of $55 \mathrm{phr}$ produces a wear of $12 \mathrm{~m}^{3} / \mathrm{s}$. Black carbon composition of $60 \mathrm{phr}$ produces a wear of 7.8 $\mathrm{m}^{3} / \mathrm{s}$. Overall, the wear reduction from Black carbon composition from $50 \mathrm{phr}$ to $60 \mathrm{phr}$ is $44 \%$. Compared to the wear on the commercially tire compound, the reduction in wear on the tire compound produced by this work reached $56 \%$.

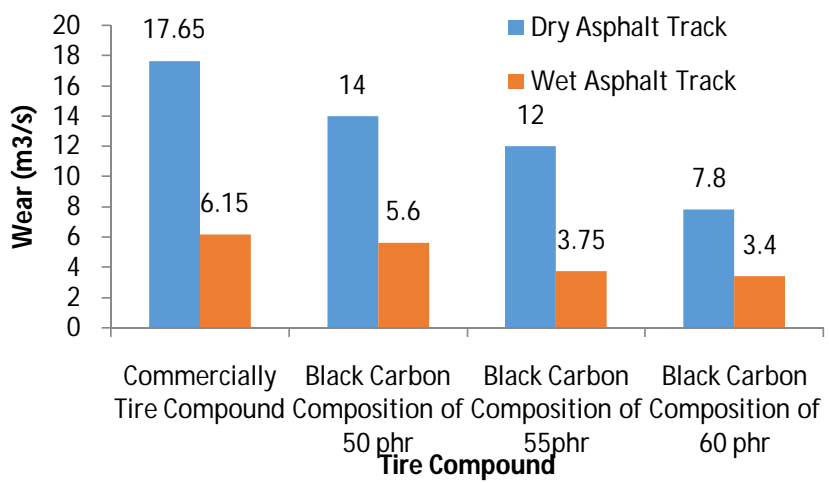

Figure 4: Effect of black carbon content on wear in wet and dry asphalt track and its comparison to commercially tire compound.

Figure 4 also shows the same tendency of wear if the tire compound is operating in a wet asphalt track operating condition. Tire compound wear tend to decrease with increasing black carbon content. Black carbon composition of $50 \mathrm{phr}$ produced a wear of $5.6 \mathrm{~m}^{3} / \mathrm{s}$. Black carbon composition of $55 \mathrm{phr}$ produced a wear of $3.75 \mathrm{~m}^{3} / \mathrm{s}$. Black carbon composition of $60 \mathrm{phr}$ produced a wear of $3.4 \mathrm{~m}^{3} / \mathrm{s}$. While commercially tire compound had a wear of $6.15 \mathrm{~m}^{3} / \mathrm{s}$. This means that the tire compound produced in this work experienced a reduction in wear of $45 \%$ on the wet asphalt track operating conditions.

Operating conditions affect the performance of the tire compound. It can be seen in Figure 4 that there was a decrease in wear on each specimen of the tire compound in wet asphalt track. Commercially tire compound has decreased wear by $65 \%$. Black carbon composition of $50 \mathrm{phr}$ has decreased wear by $60 \%$. Black carbon composition of 55 phr has decreased wear by $69 \%$. Black carbon composition of $60 \mathrm{phr}$ has decreased wear by $56 \%$. The average reduction in wear experienced by tire compounds in wet asphalt track operating conditions is $63 \%$

Grip coefficient testing did not show significant differences with the addition of black carbon composition both in the dry asphalt track and wet asphalt track operating conditions (Figure 5). However, there was a decrease in the grip coefficient on the tire compound used in the wet asphalt track when compared to the use in the dry asphalt track condition. Commercially tire compound has decreased grip coefficient by $12 \%$. Black carbon composition of $50 \mathrm{phr}$ has decreased grip coefficient by $12 \%$. Black carbon composition of $55 \mathrm{phr}$ has decreased grip coefficient by $12 \%$. Black carbon composition of $60 \mathrm{phr}$ has decreased grip coefficient by $12 \%$. The average reduction in grip coefficient experienced by tire compounds in wet asphalt track operating conditions was $12 \%$. 


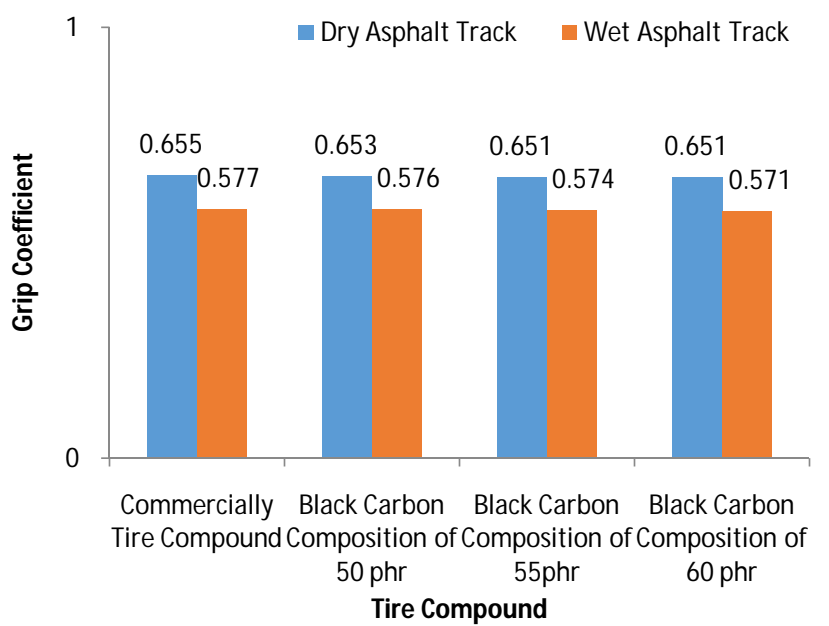

Figure 5: Effect of black carbon content on grip coefficient in wet and dry asphalt track and its comparison to commercially tire compound.

\section{CONCLUSIONS}

From this work, it can be concluded that the hardness and the tensile strength of the tire compound increase with increasing black carbon composition. While the wear of the tire compound decrease with increasing black carbon composition. This means an increase in wear resistance with increasing black carbon composition. On the other hand, wet asphalt track operating conditions reduce wear by an average of $63 \%$ compared to wear that occurs in dry asphalt track operating conditions. There were no significant differences of grip coefficient when black carbon increased. However, grip coefficient will decrease by $12 \%$ when operating conditions change from dry asphalt track to wet asphalt track

\section{ACKNOWLEDGEMENT}

Authors would like to acknowledge Ministry of Higher Education of Republic Indonesia, Mechanical Engineering Laboratory of UniversitasMuhammadiyah Surakarta and Mechanical Engineering Laboratory of Universitas Gajah Mada for material preparations and mechanical testing.

\section{REFERENCES}

1. Amari, T., Themelis, N. J., \&Wemick, I. K. (1999). Resource recovery from used rubber tires. Resources Policy, 25(2), 179-188. doi:https://doi.org/10.1016/S0301-4207(99)00025-2

2. Carcaterra, A., \&Roveri, N. (2013). Tire grip identification based on strain information: Theory and simulations. Mechanical Systems and Signal Processing, $\quad 41(1-2), \quad 564-580$. doi:10.1016/j.ymssp.2013.06.002

3. Chae, Y., \&An, Y.-J. (2017). Effects of micro- and nanoplastics on aquatic ecosystems: Current research trends and perspectives. Marine Pollution Bulletin, 124(2), 624-632. doi:10.1016/j.marpolbul.2017.01.070
4. De Groot, S., CentenoRicote, F., \& de Winter, J. C. F. (2012). The effect of tire grip on learning driving skill and driving style: A driving simulator study. Transportation Research Part F: Traffic Psychology and Behaviour, 15(4), 413-426. doi:10.1016/j.trf.2012.02.005

5. Ella, S., Formagne, P.-Y., Koutsos, V., \& Blackford, J. R. (2013). Investigation of rubber friction on snow for tyres. Tribology International, 59, 292-301. doi:10.1016/j.triboint.2012.01.017

6. Funatsuki, A., Shiota, K., Takaoka, M., \&Tamenori, Y. (2015). Forensic analysis of tire rubbers based on their sulfur chemical states. Forensic Science International, 250, 53-56. doi:10.1016/j.forsciint.2015.02.022

7. Heinrich, G., \&Klüppel, M. (2008). Rubber friction, tread deformation and tire traction. Wear, 265(7-8), 1052-1060. doi:10.1016/j.wear.2008.02.016

8. Hu, J., Rakheja, S., \&ZhangY. (2019). Tire-Road Friction Coefficient Estimation under Constant Vehicle Speed Control. IFAC-PapersOnLine, 52(8), 136-141. doi:https://doi.org/10.1016/j.ifacol.2019.08.061

9. Kole, P. J., Löhr, A. J., Van Belleghem, F., \& Ragas, A. (2017). Wear and Tear of Tyres: A Stealthy Source of Microplastics in the Environment. International Journal of Environmental Research and Public Health, 14(10), 1265. doi:10.3390/ijerph14101265

10. Lee, W. H., Kim, J. Y., Ko, Y. K., Reucroft, P. J., \&Zondlo, J. W. (1999). Surface analysis of carbon black waste materials from tire residues. Applied Surface Science, 141(1-2), 107-113. doi:10.1016/s0169-4332(98)00600-x

11. Näkki, P., Setälä, O., \&Lehtiniemi, M. (2017). Bioturbation transports secondary microplastics to deeper layers in soft marine sediments of the northern Baltic Sea. Marine Pollution Bulletin, 119(1), 255-261. doi:10.1016/j.marpolbul.2017.03.065

12. Salehi, M., Noordermeer, J. W. M., Reuvekamp, L. A. E. M., \&Dierkes W. K. (2019). Measuring rubber friction using a Laboratory Abrasion Tester (LAT100) to predict car tire dry ABS braking. Tribology International, 131, 191199.doi:https://doi.org/10.1016/j.triboint.2018.10.011

13. Sattayanurak, S., Sahakaro, K., Kaewsakul, W., Dierkes, W. K., Reuvekamp, L. A. E. M., Blume, A., \&Noordermeer, J. W. M. (2019). Synergistic effect by high specific surface area carbon black as secondary filler in silica reinforced natural rubber tire tread compounds. Polymer Testing. doi:https://doi.org/10.1016/j.polymertesting.2019.1061 73.

14. Sengloyluan, K., Sahakaro, K., Dierkes, W. K., \&Noordermeer, J. W. M. (2014). Silica-reinforced tire tread compounds compatibilized by using epoxidized natural rubber. European Polymer Journal, 51, 69-79. doi:10.1016/j.eurpolymj.2013.12.010

15. Sharifzadeh, M., Akbari, A., Timpone, F., \&Daryani, R. (2016) Vehicle tyre/road interaction modeling and identification of its parameters using real-time trustregion methods. IFAC-PapersOnLine, 49(3), 111-116. doi:https://doi.org/10.1016/j.ifacol.2016.07.019 
PramukoIlmu Purboputro et al., International Journal of Emerging Trends in Engineering Research, 8(9), September 2020, 5419 - 5423

16. Shiva, M., \&Lakhi, M. (2019). Studying the effects of silica/alumina and silica/boehmite binary filler on the mechanical properties and the non-isothermal curing time of carbon black filled tyre tread composite. Composites Part B: Engineering, 107124. doi:10.1016/j.compositesb.2019.107124

17. Song, J., Tian, K., Ma, L., Li, W., \& Yao, S. (2019). The effect of carbon black morphology to the thermal conductivity of natural rubber composites. International Journal of Heat and Mass Transfer, 137, 184-191. doi:10.1016/j.ijheatmasstransfer.2019.03.078

18. Toma, M., Andreescu, C., \& Stan C. (2018). Influence of tire inflation pressure on the results of diagnosing brakes and suspension. Procedia Manufacturing, 22, 121-128.

doi:https://doi.org/10.1016/j.promfg.2018.03.019

19. Wagner, M., Scherer, C., Alvarez-Muñoz, D., Brennholt, N., Bourrain, X., Buchinger, S., Fries, E., Grosbois, C., Klasmeier, J., Marti, T., RodriguezMozaz, S., Urbatzka, R., Vethaak, A. D., WintherNielsen, M., \&Reifferscheid, G. (2014). Microplastics in freshwater ecosystems: what we know and what we need to know. Environmental Sciences Europe, 26(12). doi:10.1186/s12302-014-0012-7

20. Wright, K. R. S., Botha, T. R., \&Els, P. S. (2019). Effects of age and wear on the stiffness and friction properties of an SUV tyre. Journal of Terramechanics, 84, 21-30. doi:https://doi.org/10.1016/j.jterra.2019.04.001.

21. A. D. Anggono, N. Ernawan, and T. W. B. Riyadi, "Analysis of mechanical and metallographic properties on the joining between aluminum and brass by using the brazing method," Int. J. Emerg. Trends Eng. Res., vol. 8, no. 2, pp. 440-446, 2020.

22. E. Julianto, W. A. Siswanto, and M. Effendy, "Characteristics of Temperature changes and Stress of Float Glass," Int. J. Emerg. Trends Eng. Res., vol. 7, no. 9, pp. 228-233, 2019. 